\title{
Contributing to Nation Building: Reflections on Teaching at a Muslim Faith-Based School in South Africa
}

\author{
O. Esau \\ Department of Curriculum Studies, Faculty of Education, Stellenbosch University, South Africa \\ oesau@sun.ac.za
}

\section{Doi:10.5901/mjss.2014.v5n27p557}

\begin{abstract}
This article is a personal reflection and a self-study of my experience as an educator at a Muslim faith-based school. After teaching at this school for over two decades, I share my reflections on how a faith-based school contributes to the democratisation of society and contributes to nation building. This article provides a perspective from an educator's position using self-reflexivity and documentary evidence as research methodology. My conclusion supports the notion that a faith-based educational institution can contribute positively towards the realisation of a greater good to all and promotes a cohesiveness that is much needed in an ideal democratic society.
\end{abstract}

Keywords: Faith-based school, Muhammadeyah primary school, reflective practice, teaching and learning, self-reflexivity, nation building, Islamic education

\section{Introduction}

Teachers who are critically reflective focus their attention both inwardly at their own practice and outwardly at the social conditions ... They are concerned with issues of equity and social justice that arise inside and outside the classroom. (Larrivee, 2008, p. 343)

In the field of teacher education a wave of reflective practice washed over the profession following Schon's (1983, 1994) reminders about the importance of the link between reflection and practice. Brookfield (1995) reminds us that the literature on reflective practice is important for two reasons. First, it offers a variety of approaches to examining practice in order that we might discover and research some of the taken-for-granted assumptions that influence our approach to practice. Second, it provides opportunities for us to understand the stories of how teachers live through reflective practice, many of which we identify with personally. If learning through practice matters, then reflection on practice is critical. In reflecting about my experience and teaching career at Muhammadeyah Primary School, I hope to share and spread more light on the perceptions concerning faith-based schools. This article includes reflections on my teaching at the Muslim based primary school for over two decades from 1985 - 2008. These reflections, however, cannot be isolated from my lived experiences - those from childhood, the teachings that I received and the teaching in which I was involved in the past. My reflections were enhanced by my self-study teacher research methodology which allowed me to plan, enact and assess, while examining the impact of my efforts on student learning as shared by Samaras \& Roberts, (2011:43). Selfstudy was born from interest shown by teacher educators in studying their own practice (Samaras \& Freese, 2009). Document analysis was chosen as the secondary basis of my research because of its worth in providing relevant legitimate data from a variety of sources (Cresswell,2003). Documents included policy documents, reports from the Education Department (Coloured Affairs Department and Western Cape Education Department) about the school and reports and letters from parents and learners. The richness that this inquiry based narrative brought to my teaching at the time encouraged me to be more critical of the context in which I found myself. Today, as a contemporary teachereducator, my thinking about my teaching practice at the faith-based school (a school supported by a religious body) might have shifted, but allow me to record my experience and tell my story.

\section{Early Influences on My Ways of Thinking about Teaching and Learning}

I was born in Claremont in Cape Town in 1964, the youngest of seven children. I was part of a closely-knit community until we were forced to sell our house, because of the National Party's Group Areas Act. The first apartheid Group Areas Act was passed in 1950 as part of the then government's plan to restrict the residential and trading rights of all "non- 
whites", including for the first time the "coloureds" in the Cape (Lipton, 1986, p.23). In their opposition to the South African regime's draconian laws, many activists sacrificed their lives. A traumatic experience in our family was the killing of my uncle, the late Imam Abdullah Haron, on 29 September 1969, while he was in detention. His death, one of many among activists, was the result of the apartheid government's actions to suppress the struggle for liberation. Recently, 17 April 2014, the Order of Luthuli Gold (the highest form of recognition that South Africa bestows on deserving citizens) was posthumously awarded to him. Repressive measures such as forced removals, detention without trial and the killing of political prisoners were all attempts by the state to marginalise and subjugate the oppressed majority of the population. Marginalisation as experienced in the wider South African society was also to be found in some South African schools, as I soon discovered during my schooling career. One can understand why Althusser $(1972,143)$ long ago called the school the most important ideological state apparatus.

During my primary school years (1970-1976), I attended a Christian-based school where members of Muslim, African Traditional Religion, Hindu and other religious denominations were exposed only to Biblical Studies, as all state schools were fundamentally adhering to Christian National Education (CNE). By singing hymns and celebrating only Christian holidays, the school was contributing towards the muting of the voices of other religions and beliefs. This does not mean that I did not enjoy the hymns and the beautiful Bible stories told in class. On the contrary, I was in fact exposed to other ways of thinking at an early age. This type of schooling practice was also contributing to what Freire $(1972,10)$ termed the "culture of silence". Freire and Shor $(1987,123)$ say the phrase "culture of silence" refers to the "passive tolerance of domination". Once a social group is curbed and prevented from expressing its dreams, desires and that which makes sense to them, it could then be assumed that it is caught up in a culture of silence. So, for example, as a primary school learner from the 1970s I experienced teaching and learning in its traditional form where rote learning, memorisation and corporal punishment were the norm.

My high school career (1977-1981) was marked by important political events and developments. It was during these years - that is, the late 1970s and early 1980s - that students in most parts of South Africa, with the exception of the "white" schools, were boycotting and resisting apartheid education (Christie, 1985, 55). The high school which I attended seemed to be no different, as it was also a "non-white" school opposing the apartheid regime. Our school experienced a number of mass rallies, examination boycotts and "stayaways" during this period. While these political events influenced the "mindsets" of our students and teachers, they did not change the teaching methods of some of our teachers in the classrooms. A "talk and chalk" method of teaching, where the students had to comply passively with the teachers instructions, virtually seemed to be the only method of teaching. Memorisation of subject matter seemed to be endless.

In reflecting on my high school years I also recall how some teachers who belonged to certain political affiliations imposed their viewpoints on others. Some of them were of the opinion that religion was one of the factors that was hampering the liberation struggle for equality. Part of the reasoning of some of the teachers for not allowing freedom of belief was that religion was the opium of the people and it promoted and contributed towards maintaining apartheid. As a Muslim student I felt I was discriminated against as this school did not allow Muslim students to attend Friday (Jumu'ah) prayers. I recall the Muslim students protesting and staging a mass walk towards the nearby mosque in 1978 as an expression of their opposition to the school's policy on religion. I was, however, given a good political grounding at the high school and I learnt to understand why some people thought religion could make you docile and accept being oppressed by the state.

After I matriculated, I studied to become a teacher at the Hewat Teachers Training College (1982 -1984). At Hewat we were taught in such a way that we would later become "teacher technicians", who would treat learners homogeneously, regardless of their feelings and socio-economic backgrounds. Here I agree with Kallaway $(1984,372)$, who says that the technological mode of rationality is not necessary wrong in itself; the problem is that its application to social and educational issues to the exclusion of all other modes of knowing means that it tends to act as a lens which focuses only on certain issues and avoids others. Most aspects of my teacher training were firmly rooted in Fundamental Pedagogics, an approach that may at times have tended to deny the political implications of ideology in education. According to many activists and academics, it was an instrument to justify the South African government's position on apartheid and education. After completing the teaching diploma course at Hewat Teachers Training College, I started teaching at the faith-based school that I describe and reflect on in this article.

\section{Entering the Muslim Faith-Based School}

When I started teaching in the 1980s, a host of new Islamic schools were established in South Africa, but the school where I was offered a post had been around since 1929. I agree with Niehaus (2011), who notes that in South Africa the 
emphasis of Muslim schools is on educating children according to the values, norms and traditions of Islam as interpreted by the respective governing bodies, principals and teachers. This is achieved by, among other things, offering special Islamic instruction, praying together, introducing special dress codes and observing the Islamic calendar.

At the Muslim faith-based school where I began teaching, Islamic subjects played a central role in creating a religious ethos and shaping religious identity at the school. At this school Islamic studies and the studying of Arabic were included in all the grades of the school. Islamic studies included the basic knowledge of the practices and history of the faith. The Arabic lessons were mostly structured around reading. The aim was to strengthen the learners around reading the Quran. The school also held Thuhr (midday) prayers every day and prayers were usually held in Arabic in the mornings and afternoons. When I arrived at the school for the first time and heard the Fatiha (opening verse in the Quran) I was emotionally moved. It was as if my two worlds had come together. One world was attending secular school in the day and the second world attending 'slamse' school (Muslim school) in the afternoon or evening.

Coming to the school with my psychological baggage and my cultural capital and meeting up with learners with their baggage and their cultural capital made the common faith-based school a melting pot in its own right. As a teacher I was but one of the people interacting with the learners. There were also still their parents, peers, other teachers and more knowledgeable others who may have impacted on their learning. My teaching was therefore only one of many factors that influenced the speed and extent to which those learners could close the gap between their actual and potential levels of performance (O'Brien and Guiney 2001, 116). In other words, the mental activities of each of the learners and their individual meaning making of the worlds in which they live need to be understood along with their social and historical situatedness (Bell 2005, 43).

As a Muslim-based school, it was one of few missionary schools that flourished both in attracting a number of learners and developing its physical building infrastructure during the apartheid era, when Christian National Education was prioritized. The initiative by the Cape Muslim community to provide its own schooling since 1913 has been documented by Ajam $(1986,1989)$. They were called Moslem Mission Schools, following the trend of Christian Mission Schools. By 1956 fifteen such schools had been established throughout the City of Cape Town (Ajam 1986; Ajam 1989). The schools provided jobs for Muslim educators who could not get posts at Christian based schools and for Muslim children whose parents were concerned about the dominant Christian ethos at both state and missionary schools.

The reasons for the establishment of the Muslim primary school where I taught were clearly outlined by one of the school's former principals, Rashaad Jedaar (1992:1):

Muhammadeyah was born out of a need in the Muslim community at the Cape, and Wynberg in particular, for a school with an educational curriculum that would provide its children with the traditional "religious" education in addition to the tools to participate actively and creatively in the socio-economic life of the country. An education that would inculcate the values of Islam.

This primary school initially started out as a Muslim missionary school in 1929 with eleven learners (pre-school to Standard 3) and is now a public school under the jurisdiction of the Western Cape Education Department, in line with the rules and regulations of the South African Schools Act (1996). The Act made provision for only two types of schools: public and independent schools. Unlike many other Muslim schools that took the independent schools option, Muhammadeyah primary chose to become a public school. In this way it received more support from the government but also maintained its Islamic identity as it attracted mostly Muslim learners. The school justified its existence as a Muslim faith-based school by providing a good integrated Islamic programme. Parents preferred this public school as both religious and secular subjects were being taught.

Initially as a beginner teacher, I recall receiving regular visits from my principal, who suggested that my class control was too weak since the learners were talking too much in class. The advice given was that instead of aimless noise, learners had to be exposed to recitation (Batcha) of the Holy Quran. This would not only enhance their spirituality, but also their good morals as human beings. This was followed up with regular class visits from my department head, whose duty (as I soon realised) was to check the books of the learners and their cleanliness. In a consistent way learners were encouraged to be neat and clean according to the cleanliness (Tohaarah) guidelines and rituals of the Quran and Sunnah (Hadith).

I soon realised that in order to become accepted as an 'insider' in the school I had to follow the path (Tariqa) of those experienced teachers who were there before me. It did not take me long to become the disciplinarian the school demanded me to be. It is an easy task to regiment learners. In being more authoritarian I became an efficient teacher and more accepted among my teaching colleagues. I seemed to dominate all discussions in class and the learners responded exactly the way I wanted them to. It would be appropriate to quote an extract from my inspector's report of 1989, "The educator teaches with authority and has a good class control ..." Although I felt good about the reports that I was getting from the inspector and the principal at that time, I somehow felt a bit uneasy about the traditional methods of teaching I 
was implementing in my classes.

My understanding of being a teacher was at odds with my classroom practice. A teacher must consult (make Shura) and most of all make use of good action (Ta'dib). The concepts that frame Islamic Education is aptly clarified by Waghid (2011, 2-4)

Islamic education can most appropriately be framed according to three interrelated concepts: tarbiyyah (rearing or nurturing), ta' lim (learning/instruction) and ta' dib (good action). ... A maximalist account of learning, on the other hand, does not entirely reject rote learning per se, but argues that learning is more a matter of public deliberation (shura)

What inspired me at that time to become a more democratic teacher was amongst other things such as antiapartheid political gatherings and boycotts, the BEd Honours course that I studied at the University of the Western Cape. According to Nicolson and van den Berg $(1990,3)$

$\ldots$ the institution (UWC) has developed to a point in its history where it is without doubt the university in this country that has most unequivocally committed its teaching, research and service activities to an anti-apartheid and to the postapartheid ideal. ... The discourse generated by these challenging conditions, the social proximity of practice to the University's theoretical activities, make of this institution as intellectually charged and vital an environment as anyone can wish to be working in.

Many of the modules that I did during my BEd encouraged me to reflect on the realities of education and society. I started to understand more about the plight and hardships experienced by the economically disadvantaged and culturally deprived students. I started to understand more about the effects of apartheid on the large mass of people in our country. The readings of Freire, McLaren, Giroux, Gramsci, Apple, Althusser, and Bowles and Gintis exposed me to the role that schools play in perpetuating or contesting the status quo in society. As a result of this greater awareness, I started to become more concerned about the wellbeing of my learners. I strongly felt that I needed to democratise my teaching my own work place. In my attempt to transform my teaching I had to go on a journey of change. To assist me on my journey I enrolled for an Action Research Master's programme at the University of the Western Cape. This course instilled in me renewed vigour, enthusiasm and a more comprehensive perspective on schooling and education. It was during this period that South Africa had a change in government and during 1994 Nelson Mandela became the first ever democratically elected president of South Africa.

On paper the apartheid era was drawing to a close and this led to large-scale retrenchments in government sectors. Muhammadeyah primary was forced to decrease its staff because of the changes in teacher-pupil ratios as prescribed by the education policy. As the school was situated in Wynberg a "coloured" area, the new government had to prioritise equity and also spend more on the previously disadvantaged "black" areas such as Khayalitsha and Nyanga. This was somewhat confusing to some people as they were not aware that "coloureds" were also on a very small scale more advantaged in the apartheid system. Having also struggled and also being deprived of the vote during the apartheid era, some of the Muslim parents and also teachers of Muhammadeyah felt disappointed in the new African National Congress government. They expected to be given a better deal after the demise of apartheid, but felt an injustice when they had to lose teachers because of the government's retrenchment initiatives. Deciding on who must leave the school was not easy as teachers at the faith-based school felt a special commitment of belonging to the institution. This was indeed an unpleasant period at the school, especially as staff members had to rationalise and vote who must go or stay on at Muhammadeyah.

At the time it was clear that political imperatives superseded educational priorities. After so many years in which the majority of people in South Africa had been deprived of the right to equal formal access, and even more importantly to epistemological access, the new government felt very strongly compelled not to wait any longer to put in place a new education dispensation. The years after 1994 saw the implementation of Curriculum 2005, which promoted an outcomesbased approach to education. Curriculum 2005 has its roots and precedents in the struggles of social movements around education and the curriculum in the pre-apartheid period, but it is also a 'transformation' of those struggles born in a context of social compromise (Motala \& Vally, 2002, 180; see also Cross, Mngadi \& Rouhani, 2002). Negotiations between the then apartheid government and civil society in the National Education and Training Forum in 1993 were followed by a process of curriculum "cleansing" immediately after Bhengu took office in 1994.

Although the legacy of apartheid will remain with us for a long time, one can also see at a number of levels in our education system that the cracks of the new planned education initiative precipitance is starting to show its negative side. Jansen $(2001,272)$ warned that "the making of educational policy in South Africa is best described as a struggle for the achievement of a broad political symbolism to mark the shift from apartheid to post-apartheid society" rather than entailing a serious consideration of the new policies' effects on especially those who were marginalised before. Along the same lines, Morrow $(2007,2)$ argues that "we increasingly reach for curriculum reform and shallow notions of accountability in our desperate attempt to accomplish the much-to-be-desired transformation of education which does not 
yet seem at hand". Underlying both these concerns is the issue of lack of time to consult cutting-edge research and to spend time to think carefully through the pros and cons of new curriculum policies and their implementation. I think to avoid the conflict and the demands made by the government on principals during this period, Sedick Gamiet after being principal for only two years at this faith-based school, rather opted for early retirement. His post was filled in January 1997 by Ebrahim Ismail who continues to head the school today. As a former learner at Muhammadeyah (Sub A in 1959), he had been groomed and socialised within the school's immediate community. It was in 1997 that I also assumed the position of deputy principal at the school. As mentioned earlier, the school enjoys a long lineage of family ties going as far back as 1929, when it was established.

Now, in 2013, although it is a public school, this faith-based school still maintains its Islamic ethos and still upholds its original aims and objectives from the time of its inception. The school, which was initially an Afrikaans-medium institution, has now been changed into an English-medium school. As a Muslim school, it offers a third language, Arabic, as well as Islamic Studies in its curriculum. Recently the Governing Body purchased the house adjacent to the school in its quest to acquire more land. Although the school has a Muslim base, it attracts learners from other cultural backgrounds as well. Given the support it gets from the community, there appears to be a need for community schools such as Muhammadeyah in South Africa.

\section{Challenges Facing Muhammadeyah in a Post-Apartheid Era}

In a post-apartheid era the school faced the challenge of becoming more inclusive of the South African "Rainbow Nation". As part of the "multicultural landscape" in our diverse society, the faith-based school has a role and responsibility in the pursuit of the goals of multicultural education. This role and responsibility apply both in respect of the school's constituent community and the secular society, as the school encourages its learners and families to value positively differing religious viewpoints and their cultural expressions; to the wider society, as the school demonstrates its commitment to cultural awareness and inclusion. In consequence, faith-based schools, such as Muhammadeyah can serve the greater public good over and above the good they can serve within their own faith-based communities.

I want to concur with Banks, $(2006,208)$ that a clearly, thoughtfully developed cultural identification will result in a "better citizen". In considering cultural identity, the religious dimension is both relevant and inescapable since, on the one hand, the religious frameworks of Islam locate the individual in relation to an understanding of the nature of God and since, on the other hand, religious understanding is expressed in cultural contexts through the behavioural and ethical expectations that have their origins in an understanding of faith. Consequently, faith-based schools are uniquely placed to provide for the thoughtful development and clarity of understanding in their communities for which Banks (2006) calls. Faith-based schools seek to develop a sense of identity in all their students, arising from their religious framework of understanding. Moreover, the religious/cultural identity that is supported by faith-based schools impacts on more than "religious" families, since families that do not themselves share a personal faith commitment may also enrol their children in a faith-based school. Amongst the reasons for such enrolment may include a desire for children to be exposed to the moral education that the school offers, or to become familiar with the cultural traditions of the school, and to participate in the various rituals such as Ramadaan, Eid-ul-Fitr, Mouloud and Gadats, etc.

The faith-based school can play its part in developing a more nuanced understanding of citizenship in this way through its religious education programmes of personal development and citizenship education. With its understanding of faith, culture and behavioural imperatives, the faith-based school can, through its programmes, help its students and its wider society to understand culture-specific rights and responsibilities. Moreover, within these programmes the school can integrate and critique these rights and responsibilities within a broader framework applicable to all citizens as outlined through the United Nations Universal Declaration of Human Rights (United Nations, 1948) and the Universal Declaration on Cultural Diversity of the United Nations Educational, Scientific and Cultural Organization (UNESCO, 2002).

However, the challenge for the faith-based school is to evaluate its education against both underpinning universal human values and its faith tradition is worth taking up, since the stakes are high for all of us living in multi-ethnic and multi-religious societies. Banks $(2006,208)$ observes that "unity without diversity results in hegemony and oppression; diversity without unity leads to Balkanization and the fracturing of the nation-state".

As a teacher that had the privilege to teach for more than two decades at a Muslim faith-based school, I strongly believe that faith-based schools such as Muhammadeyah, despite of the obvious challenge of becoming exclusive provides a good basis for its learners to become confident to engage and deliberate and most of all cultivate a concept of sharing and mutual respect for other people, more so in a post-apartheid era. 


\section{Conclusion}

The article has attempted to reflect from an insider's perspective on how a teacher with 'lived' experience of both a Muslim and secular society, as well as a teacher-researcher and a reflective practitioner views the challenges facing faithbased schools. Although my experience was in a Muslim faith-based school in a South African context, I concur that it holds value for other faith-based schools in other parts of the globe as well. I agree with McNiff (2007), the practice of holding oneself accountable for what one does is, I believe, the grounds for theories of peace education that have the potential for influencing the development of what could count as sustainable peaceful practices.

As a faith-based school, Muhammadeyah primary promotes and speaks to moral concerns about the nature of a just society in that its policy and practice show commitment to social inclusion, social justice, tolerance, mutual respect and equity.

In strengthening its policies of sharing and caring, the faith-based school contributes to the greater good of all and promotes a cohesiveness that is much needed in our attempts to promote better teaching and learning in post-modern society. What has been implicitly acknowledged and emphasised in this article is the notion that faith-based schools have a definite space in society and that its existence remains critical to the cause of nation building.

\section{References}

Althusser, L. 1972. Ideology and ideological state apparatuses. In B. Cosin, (ed.). Education: structure and society. Harmondsworth: Penguin.

Ajam, M. 1989. Islamic schools of Cape Town as agencies of socialisation. Journal for Islamic Studies 9: 70-98.

Ajam, M. 1986. "The Raison De' Etre of the Muslim Mission Primary School in Cape Town and Environs from 1860 to 1980 with Special Reference to the Role of $\mathrm{Dr}$ A. Abdurahman in the Modernisation of Islam-Orientated Schools." PhD dissertation, Faculty of Education, University of Cape Town, Cape Town.

Banks, J.A. 2006. Race, culture and education. The selected works of James A Banks. New York: Routledge.

Bell, B. 2005. Learning in science: The Waikato Research. London: Routledge Falmer.

Berdien, A. 1998. Interview. Cape Town.

Brookfield, S. 1995. Becoming a critically reflective teacher. San Francisco : Josey-Bass.

Chisholm, L. 2003. The State of Curriculum Reform in South Africa. In J. Daniel, A.Habib \& R. Southall (eds.). State of the Nation: South Africa 2003-2004. Cape Town: HSRC Press.

Chisholm, L. 2005. The State of South Africa's Schools. In J. Daniel, J. Lutchman \& R. Southall (eds.). State of the Nation: South Africa 2004-2005. Cape Town: HSRC Press.

Cresswell, J.W. 2003. Research design: Qualitative, quantitative and mixed methods approaches. Second edition. Thousand oaks, California: Sage Publications.

Cross, M., Mngadi, R. \& Rouhani, S. 2002. From policy to practice: Curriculum reform in South African Education, Comparative Education 38 (20). 171-187.

Da Costa, Y \& Davids, A. 1994. Pages from Cape Muslim History. Cape Town: Shuter \& Shooter.

Da Costa, Y. \& Meerkotter, D.A. 1994. Dug-up customs and implanted foreign crops: The [de] colonization of education in South Africa. In Y. Da Costa, C. Julie \& D.A. Meerkotter (eds.). Let the voices be heard: Process and practice in education. Cape Town: Wyvern Publications.

Fataar, M.A. 2003. Comparative Study of Muslim Schools in the Cape. Unpublished article. Cape Town: University of the Western Cape. Freire, P. 1972. Pedogogy of the oppressed. Harmondsworth: Penguin.

Freire, P. \& Shor, I. 1987. A pedagogy for liberation: dialogues on transforming education. London: Macmillan.

Jansen. J \& Sayed Y. 2001. Implementing Education Policies: The South African Experience. Lansdowne: UCT Press.

Jedaar, M.R. 1992. Muhammadeyah: 1929-1992. Unpublished paper. Cape Town.

Kallaway, P. 1984. Apartheid and education. Johannesburg: Ravan Press.

Larrivee, B. (2008). Development of a tool to assess teachers' level of reflective practice. Reflective Practice, 9(3), 341-360.

Lipton, M. 1986. Capitalism and apartheid: South Africa, 1910-1986. Cape Town: David Philip.

McNiff, J. 2007. 'My story is my living educational theory' in D.J. Clandinin (Ed.) Handbook of Narrative Inquiry: Mapping a Methodology. Thousand Oaks, Sage, pages 308-329.

Morrow, W. 2007. Learning to teach in South Africa. Cape Town: HSRC Press.

Motala, S \& Vally, S. 2002. People's education: From people's power to Tirisano. In P. Kallaway (Ed.). The history of education under apartheid: The doors of learning and culture shall be opened. Cape Town: Maskew Miller Longman.

Nicolson, S \& van den Berg, O.C. 1990: Teacher transformation in the South African context: an action research approach. Unpublished paper. University of the Western Cape.

O'Brien,T. and D. Guiney. 2001. Differentiation in teaching and learning: Principles and practice. New York: Continuum.

Samaras AP \& Freese AR. 2009. Looking back and looking forward: an historical overview of the self-study school. In CA Lassonde, S Galman and C Kosnik (eds), methodologies for Teacher Educators. Boston and Taipei: Sense Publishers. 
Samaras AP \& Roberts L 2011. Teachers take charge of their learning. Retrieved on 15 January 2014 from http:www.learningforward. org.

Schon, D. 1983. The reflective practitioner- how professionals think in action. New York: Basic Books.

Schon, D. 1994. Teaching artistry through reflection-in-action. In H. Tsoukas (Ed.), New thinking in organizational behaviour (pp. 235249). Oxford: Butterworth-Heinemann.

Waghid, Y. 2011. Conceptions of Islamic Education: Pedagogical framings. New York: Peter Lang.

Rules of the Moslem Education Trust filed with Mortgage Bond No. 5958 d.d. 12 July 1929.

UNESCO. (2002). Universal Declaration on Cultural Diversity. Paris: UNESCO.

United Nations. (1948). The Universal Declaration of Human Rights. New York: United Nations. 